\title{
Territorial Systems and Valley Communities in the Area of the Straits of the Metropolitan City of Reggio Calabria
}

\author{
Maurizio Malaspina ${ }^{1, a}$ \\ ${ }^{1}$ Mediterranea University of Reggio Calabria - PAU - Department of Heritage, Architecture, Urban \\ Planning, Via Salita Melissari - 89124, Reggio di Calabria, Italy \\ amaurizio.malaspina@unirc.it
}

Keywords: Cultural Heritage, Enhancement, Ecodistretto, Gallico Valley, Local Development.

\begin{abstract}
The present study deals with the theme of district policies applied to the enhancement of territorial systems suited to integration, highlighting the extraordinarily important role of participation and involvement in every stage of the process area. The research has focused on the codification of a model of supply network capability, the Ecodistretto, and has experienced the stages of start-up in a pilot area of the Strait, the antipeninsular sub-system of the Gallico Valley.
\end{abstract}

\section{Systems and Valley communities in the area of the straits}

The Area of the Strait, widely known as the Calabrian and Sicilian land overlooking the Strait of Messina, (then named using different epithets such as Metropolitan Area, Strait Province, Strait Town), is characterized by the strong presence of antipeninsular territorial sub-systems identified by the watercourse of streams flowing into the sea of the Strait. Particularly on the Calabrian side, given the presence of the Aspromonte massif extending along the coastal regions with its complex and degradated altimetry, the valleys mark the territory characterizing it under a morphological, productive, landscape, historical and socio-cultural profile.

The peculiarity of this Strait articulated by antipeninsular zones and marked by watercourses, was until now poorly highlighted and implemented in urban planning and programming development tools. From the 1972 urban planning scenario of the "Great Reggio", which annexed the small satellite districts to the town, until the "Piano Quaroni" of the early 1970s which drew a compact city along the coast, the planning of the Strait has always moved with a particular attention to the peninsular setting, tending to a long-lasting connection with the other side in an urban agglomeration approach rather than a polycentric one. This approach has never been changed, even in recent years, by the integrated programming promoted by the EU Structural Fund Policies because the integration mindsets that have linked the territories to the taken actions, did not respond to the real community, landscape, cultural and productive systems aptitudes, but to political needs and administrative relevance. This is the reason for which the territorial system of the Strait, strongly inclined to integration, has never emerged until now as such, being that the valleys have been recognized as penetration road networks providing access to its interior. Not only towards the "internal areas" - which would at least evaluate opportunities in cost-benefit terms - but merely to some isolated zones to which has been given an impersonal role and an overestimated potential as for the production of values (Calabrò, Della Spina, Sturiale, 2010).

From 1972 onward, those territories with an highly innate peculiarity and specificity and defined areas with a strong identity, have seen their role and their potential significantly resized by a careful planning only careful to the "forced" urbanization along the coast. Since the years of the housing boom (1970s-1980s), the city grew thanks to the gradual annexation of agricultural areas, gradually erasing the peculiarities of a polycentric town and triggering a rapid process of deconcentration of the marginal territories emptied by administrative autonomy and by socio-cultural and economic identity. However, the territories of the valley in the Area of the Strait - maybe due to their characteristic geomorfological conditions or to that kind of difficulty to accessing transformations determined by the loss of links (this aspect has often given to Calabria areas with a strong identity; just think to the Grecanica/Hellenistic Area) - have better resisted to the dependency process imposed by the concentration of services, keeping their economic and socio-cultural tissues and 
making it a still important potential base for the whole area of the Strait. The Valleys of the Straits, despite having been heavely affected in their landscape values and in their architectural characters by isolated urbanizations (often abusive) near the estuaries or by removing abusive activity, or by the abandonment of primary production activities (the orange in Villa San Giuseppe, the lemon in the area of Catona, the bergamot in Sant'Agata and so on), are still important territories retaining the characters to become an "area-program", that is paradigm-territory on which intervening with an integrated development action aware of consolidating an inter-municipal, widespread and balanced network. If all this has never been read in its potential key inside the often obsolete and outdated planning tools (as well as all the municipalities have initiated procedures for the new planning prescribed by the Regional Planning Law), nor in the strategic planning (once again drawn without an important connection to the real system vocations of territories), there are many relevant signals reflecting a turnaround in progress which are emerging through the action of a social and associative tissue that for years continue seeing the Strait area a system of areas having a positional, cultural, environmental and naturalistic-testimonial power (as referring to the Mediterranean Sea). It is in this frame that the recent establishment of the metropolitan city of Reggio Calabria - on which there is a more intense scientific debate ahead of the birth of the new administrative reality - can represent a significant opportunity.

The main thing is to overcome the widespread view that sees the functional conurbation vision of the Strait, leading it to an established vision of metropolitan city (or rather stop it, since the trend is taking place) and directing the development towards the integration of local environments hugely historicised and full of landscape, environmental, cultural and historical values as the valleys are (Fig.1).
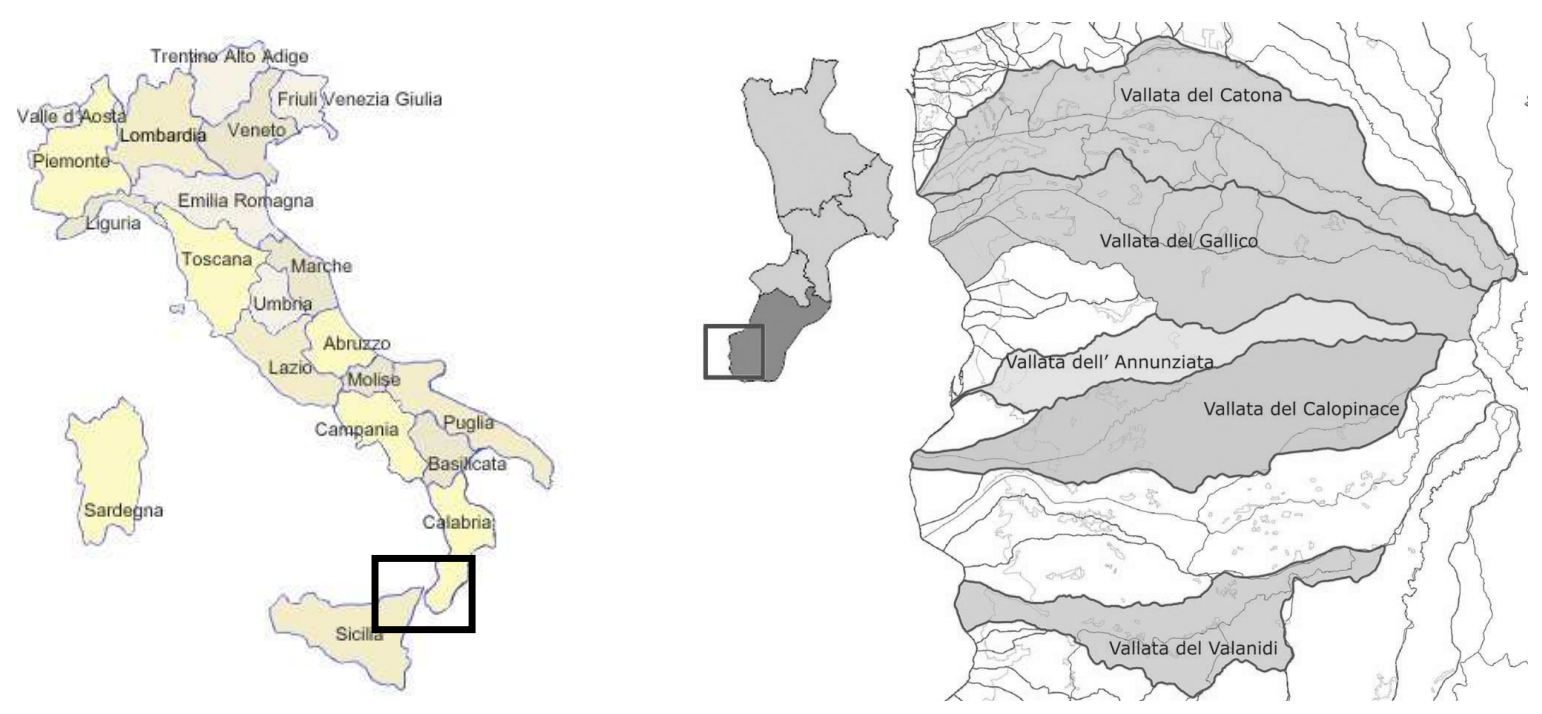

Fig. 1, System of Valleys in the Area of the Strait.

Under a metropolitan point of view the subsystems of the Valley of the area of the Strait, must regain the role of territories bearer of the historical identity of the Strait, on which you don't need to intervene using only the "traditional" measures of economic growth directed to the production of goods and services, but rather adapting those measures able to link economy and territory around the social fruition of their own identity and values ant to the urban and ecological regeneration of the areas. (Ziparo, 2005).

From this point of view, the study based on eco-districts - i.e. intersectorial district policies applied to the vocation of the places and tested for the first time over the Valley of Gallico with the result of producing the first Eco-district managed as a public-private consortium - moves exactly in the direction of an innovative scenario of development sustainability for the Strait, through the creation of a system thematic territorial district of the Valley. 


\section{The fundamental networks of the district policies}

The district policies, before focusing the reasons of their existence and the functions of their usefulness in a conceptual economic basis, put their attention in a social structure of which it seems hard to define its boundaries but that definitely has a strong characteristic: that of being networked. (Ricciardi, 2008). The network theory is an aspect that, while it deeply defines the district, it is hardly ever taken into account in defining the successful elements of a district policy for the development. The fundamental role of the network when defining the district is to simply confirm the existence of a horizontal strategic relationship in an area strongly inclined towards the development in order to establish the necessary but not sufficient conditions to create a solidarity structure and, therefore, an assumption to spread the knowledge. It's necessary but not sufficient because, the birth of a district includes a number of other essential conditions, such as the willingness to cooperate with others, the conditions of the context, the legal configuration to set up a new legal identity which is not obvious in front of a simple precondition. It's the network element of a District - with the multiplication of the genres that have characterized its recent spread in terms of models, governance and productive branch - that helps defining the overcoming of the mere need, useful to reach the "productive concentration" for the district, namely the almost natural mechanism that led to the birth of a network of economic satellite actors of a productive costeffective company. This led to a drastic reduction of the lasting of the district, extremely linked to the choices of the large productive area that is one of the reasons at the base of the birth and existence of the district. On the other hand, the next step led to the industry specialization focused on a horizontal organization and aimed at bridging the gap size by optimizing the quality parameters through the network. The question is: who fixes the criteria for accrediting the entities to become part of a network of the district if it lacks the polarizing company that settled the very function of the district and its organizational and productive position? The answer could be generically found in the territory, namely in its node components and in its relational systems involving the nodes themselves, or maybe in the same network definition, specified as " $a$ set of legally autonomous companies, whose relationships are based on trust liaisons and, in some cases, on contracts undertaken to achieve a single production" (Ricciardi, 2008). Basically, the network grows out thanks to the initiative of some territorial leaders, not only dimensional and productionbased, but mostly from people expressing entrepreneurial leadership and, as such, are able to organize and coordinate a chain by selecting the partners based on specific competences (everyone "does the best they can") with the aim to improve the quality of the final product and reduce costs.

As a matter of fact, it's the aim that defines the composition of the network and, as such, the production of an object or the enhancement of territorial resources involve a different articulation of the network itself, since the achievement of the objective needs specific components as part of a process. When we refer to productive districts - that are intended to produce and manufacture a product - all this results in the specialization of the various companies which contribute to the realization of the product. On the other hand, if we refer to a district eager to promote and enhance the territorial resources, the achievement of the objective mostly needs a diversification of the involved subject and, at the same time it needs diversified manufacturing sector companies but also associations, Pro-loco, local administrations, each having specific features but aiming at achieving a widespread benefit. This is the logical system of cross-cutting, cultural and rural districts, in which the productive factor interacts with thousands of causes entering the social and cultural landscape of rural and local communities

\section{Organised networks in the valley of the area of the Strait: the eco-districts}

The eco-district concept that has been proposed and tested for the area of the Strait through the territorial system of antipeninsular valley, focuses on the organization of a functional network of productive supply chains in a territorial context able to develop as an integrated system and dedicated to integration. The district to which the eco-district refers, recall the definition that the art. 13 of the Legislative Decree 18 May 2001 no. 288 gives referring to the rural district, given that it 
is considered extremely inclined to recognize a wide range of scenarios established by the rural area. As a matter of fact, if the rural districts are intended as local systems "characterized by an intrinsic historical, cultural and productive identity deriving from the integration between agriculture and other local activities as well as the production of goods or services having a particular specificity connected to the local and natural traditions and aptitudes", we can't identify the rural district as an "agribusiness district" (given that the territory is strongly characterized by a localized micro-chain apt to the cultivation and the diffusion of a typical specific production) or as a "touristic district" considering that the rurality of the productions embraces the touristic use of the territory or its culture (cultural district). If we relate the idea of district - i.e. an organized and functional network for the implementation and dissemination of an integrated product - to all those actions directed to production, promotion and territorial animation which focus on to the enhancement of an area dedicated to integration, following those models based on the sustainability and the use of endogenous resources (human and productive ones), then comes the concept of ecodistrict, that is a territory characterized by a system of relations (productive, commercial, cultural, institutional, etc.), progressing, in terms of preserving the environmental resources, between members working within local development. The trial focused on the start-up phase of an ecodistrict, in a pilot territory in the area of the Strait. The pilot project as a start-up process, as a preliminary and as a demonstrative phase to spread, involving the local community, public and private institutions, and with the cooperation of other actions and successful events undertaken in other territorial areas. The birth of an ecodistrict, entails a subdivision in phases starting from the identification of the territory (phase 1), which must be characterized by an extremely strong and codified productive and cultural identity, i.e. micro-territories with high productive and historiccultural specificities, with marginal economies still important from an identity and endogenous point of view. After having found the area and verified its resources, this phase is followed by the choosing of the "territorial facilitator" (phase 2), that is an active territorial entity as regards projects or a promoter of the initiative if the request comes from the territory itself. It isn't a concertative methodology (it isn't a meeting of persons considered local interlocutors) but it simply involves an instrument which "facilitates" the activities of involvement, in order to achieve the objectives. The facilitator is a "beachhead" in the territory, and his choice is focused on being the structural part of the project. The Facilitator must believe in motivation and must be willing to work for his success, even in the absence of any immediate direct benefits in economic and financial terms. Therefore, the "facilitator" allows the project to enter the territories, obtaining the necessary information useful to know the features, the potentialities, the vocations and opens the phase of the territorial involvement (phase 3). This latter is a first program line which consider the way to create territorial animation initiatives and actions in cooperation with the facilitator in order to transfer to the territory the knowledge about the project and to gain from the territory the information and the justified acceptances, that is, those entities who really want to contribute to build the required scenario for the birth of the eco-system. The phase of involvement will create the "territorial Forum" that launch the comparison on the establishment of the eco-district and on the definition of the objectives and action plan. From the activities of the Forum will result the action plan including the start-up actions and the "road map" for the construction of the management entity (phase 4).

This latter will represent the core of the project, the key step to give stability to the initiative through the creation of the subject of the management action plan of the eco-district. The laboratory will complete by supporting the creation of start-up interventions; in other words, with structural efficient interventions useful to start the activities of the eco-system and create the conditions for its enforcement. Now, the eco-district, with its objectives, its action plan and its management, can start its activity, representing a new territorial entity and a reference as for the environmental education policies and the local development. The expenses/costs borne for the purpose move in two directions: the actions for the identification of the reference territory and its "territorial facilitator", for the establishment of the Forum and for its management; the start-up actions which mainly focus on the costs used to found the manager and to enforce the eco-district. Next to these entries there are the costs for the enforcement of the action plan identified by the Forum as functional to start the 
activity, which consist of preliminary structural and strategic interventions. These are tiny basic investments (for example the creation of a website, the production of promotional material related to some lines of actions of the plan, the training of qualified personnel in environmental education activities, the creation of regional centres such as offices and operational centres, etc.) suitable to create those functional requirements useful to the new established subject to carry out his key role effectively in the local development processes of the territory affected by the eco-district.

Therefore, the basic principles of the model can be summarized as follows:

- The laboratory and experimental approach as a superior experimental and definition tool of the participation models for the development and the environmental education;

- The drawing up of a shared and participated action plan laying down the contents of the pilot ecodistrict project is enabled through an extremely motivated synergic path from the actors (even single citizens) acting like leading players, all of whom will never take advantages of investments before the birth of a new territorial entity which manages and apply the model;

- One of the two objectives of the project is the creation of a new territorial entity that is the bearer of the project instances/requests (the other is the participatory drawing up of the ecodistrict action plan). The path to get to the management and enforcement subject is suitable to create those cohesion and motivational conditions underpinning any integrated development concept.

- After the setting up of the new territorial entity, the start-up phase must be supported by small investments to create useful prerequisites to rooting and spreading the activity. Only this part of the action plan, which does not exceed $5 \%$ of the planned investments, will be part of the pilot project. The reminder part of the action plan is not supported in carrying out the pilot project under the economic profile; it will be created by the new territorial entity through synergies to be found in the market or through partnerships and collaborations, like any other private actor.

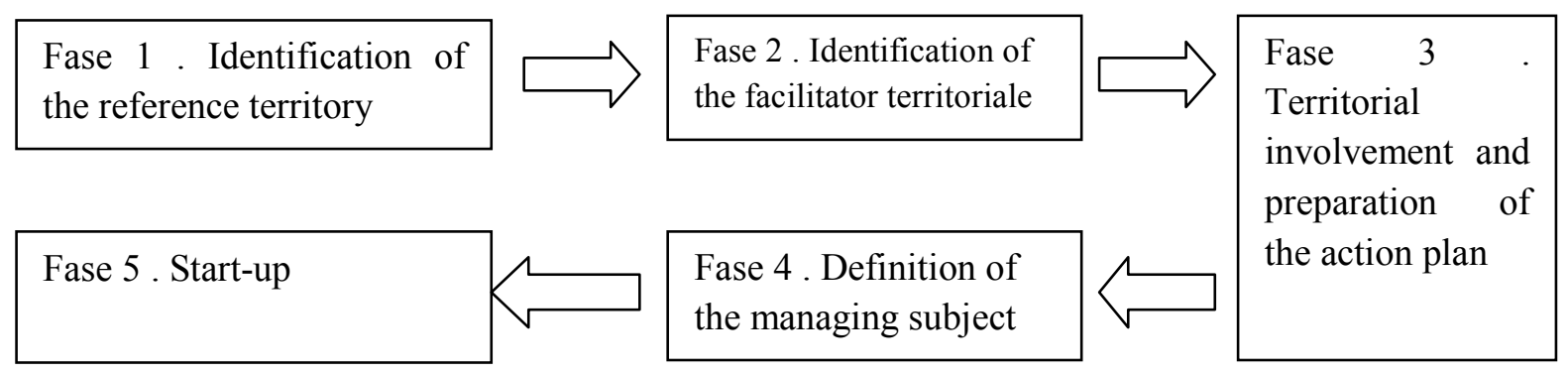

Fig. 2, Representative scheme of the birth of an Ecodistretto.

\section{Conclusions}

The search, which lasted two years, experienced a shared path towards the creation of a development governance tool built on a valley system of the Straits area, the Gallico Valley. The path went along with the territorial involvement phases - analysis and definition of the development scenarios of the reference area - until the legal establishment of the new entity, resulted in the creation of a public-private mixed consortium, (as regards the pilot project, see the Eco-district Consortium in the Gallico Valley), or rather the necessary tool useful to organize the network of public administrations, associations and enterprises sinergically operating for the enhancement of territorial resources and creating an integrated offer. 


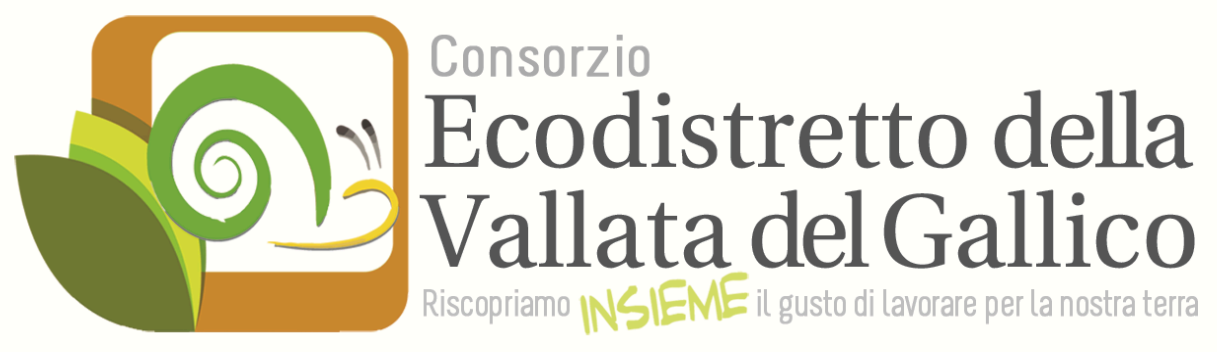

Fig. 3, The brand of the Consortium Ecodistretto of the Gallico Valley.

Therefore, the establishment of the legal entity as a result of the long experimental path about the innovative local development processes classified as a modern and effective tool to affect the dynamics of exploitation of the local resources; a new territorial leading player of the valorisation of the places having a strong historical, cultural and productive

identity.

\section{References}

[1] F. Calabrò, L. Della Spina: The cultural and environmental resources for sustainable development of rural areas in economically disadvantaged contexts. Economic-appraisals issues of a model of management for the valorisation of public assets. In 3rd International Conference on Energy, Environment and Sustainable Development (ICEESD 2013). Advanced Materials Research Vols. 869-870 (2014) pp 43-48 (C) (2014) Trans Tech Publications, Switzerland doi:10.4028/www.scientific.net/AMR.869-870.43, (2014)

[2] F. Calabrò, L. Della Spina: The public-private partnerships in buildings regeneration: a model appraisal of the benefits and for land value capture. In: 5nd KKU International Engineering Conference 2014 (KKU-IENC 2014). ADVANCED MATERIALS RESEARCH, Vols. 931932 (2014) pp 555-559 (C) (2014) Trans Tech Publications, Switzerland doi:10.4028/www.scientific.net/AMR.931-932.555, (2014)

[3] G. Cassalia, A. Sapone: La diffusione della conoscenza del patrimonio identitario come strumento per la conservazione del patrimonio storico-culturale: percorsi di laboratorio nella Vallata del Gallico, LaborEst, n.6 (2010), pp. 26-31

[4] M. Malaspina, C. Ventura: I sistemi turistici locali: valore aggiunto nei processi di sviluppo locale e scenari competitivi in Calabria, LaborEst n. 3 (2009), pp. 59-65

[5] E. Mollica: Gli obiettivi e $i$ criteri di scelta dei progetti di investimento in aree regionali svantaggiate, Quaderni del Dipartimento Patrimonio Architettonico e Urbanistico n.3 (1992), pp.107-125

[6] E. Mollica: Le politiche strutturali dell'Unione Europea per la promozione dello sviluppo locale, Laruffa, Reggio Calabria (1999)

[7] E. Mollica, M. Malaspina: Programmare, valorizzare e accompagnare lo sviluppo locale, Laruffa, Reggio Calabria (2012)

[8] A. Ricciardi: Reti di imprese. Modello organizzativo per sostenere la competitività delle Pmi italiane. Amministrazione \& Finanza, n.22 (2008)

[9] G. Soda: Reti tra imprese. Modelli e prospettive per una teoria del coordinamento, Carocci, Roma (1998)

[10] A. Ziparo: Il ritorno delle grandi infrastrutture: il progetto del ponte sullo Stretto di Messina. In AA.VV., Il ponte insostenibile, Alinea, Firenze (2005) 